\title{
Corporate Donations as a Source of Financing an Innovative Strategic Economic Plan to Strengthen the National Economy in More Than One Axis in Developing and Poor Countries: A Justified View
}

\author{
Younis A. Battal Saleh \\ B.Sc.-M.Sc.-CPA-CEA in Accounting, Lecturer and Researcher \\ E- Mail: battalsaleh@yahoo.com ORCID ID: https://orcid.org/0000-0002-4209-3132
}

\begin{abstract}
In developing and poor countries, corporate donations, which are one of the sources of financing available in those countries, are not being used effectively "in a correct and ideal way." As a result, this theoretical study presented an idea about how to manage and invest this resource in a fruitful way that contributes to strengthening the national economy in more than one axis and addressing many social problems and negative phenomena resulting from the deterioration of economic conditions in those countries, through a strategic economic plan was designed for this purpose. To a large extent, the structure of this study, the formulation of its idea and the formation of its conceptual framework depended on personal diligence, rational thinking and the researcher's imagination, supported by logical justifications. Corporate donations can be used according to the innovative strategic plan to boost the national economy in more than one axis in those countries "doubling the number of companies - strengthening the infrastructure - enhancing the state's tax revenues - contributing to solving the unemployment problem, etc. ".Also, this plan will contribute to solving many social problems resulting from the deterioration of the economic conditions in these countries. This is on the practical level, but on the theoretical level, in the field of CSR thought, this study indicated the need to adopt the concept of priority "most important" and the idea of addressing the causes of the problem, not its symptoms, as much as possible, to be included in the list of principles of CSR. Also, this study defined what is meant by the CER at the level of the country's economy as a whole, and fruitful corporate philanthropy "multi-purpose". As well as, this study explained the real interaction between the CER and the CPR at the level of the country's economy as a whole and at the level of the corporation's economy. The researcher expects that this study will receive sufficient attention from the governments of these countries and to benefit from its content in developing their financial policies and laws related to the management and investment of corporate donations in bringing about a real comprehensive development. Also, this study may be the starting point and the cornerstone of many studies and research in this field.
\end{abstract}

Keywords: Developing and Poor Countries. Comprehensive Development. Strategic Planning. Corporate Social Responsibility. Corporate Economic Responsibility. Corporate Philanthropic Responsibility. Corporate Donations. 


\section{INTRODUCTION}

According to the concept of priority "the most important", and the concept of addressing the roots of the problem, not its symptoms, as much as possible, corporate donations should be directed to finance development plans, and strengthen the infrastructure and national economy in developing and poor countries that suffer from a marked deterioration in their economic conditions. This perception can be justified as follows:

On the economic front, developing countries, and the poor in particular, suffer from deteriorating economic conditions and their repercussions on the social life of their societies. "The developing economies -classified based on per capita income level "in the worst ranks, " and poor countries that are characterized by low per capita income, a significant unemployment rate, the large number of poor and needy people in the societies of these countries." these countries are intended "concerned "in this study. These poor economic conditions are primarily responsible for serious crimes and high rates of criminality - especially economic crimes, and the exacerbation of social disease rates "such as drug addiction and prostitution," family and social problems "such as family disintegration, divorce and reluctance to marry," and unethical behaviors "such as forgery and fraud" in the societies of these countries. Despite the scarcity of resources, governments in these countries have spared no effort for social reform. With the inability of many governments in those countries to meet the requirements of economic development and social reforms at the same time, NPOs intervened to contribute to social reform programs with funding provided by people and companies. Most of the social issues and problems, and negative phenomena in developing and poor countries are the result of poor economic conditions in those countries. With funding from donor corporations, NPOs are trying to participate in solving many of the social problems and negative phenomena. The participation of these organizations may provide temporary solutions and not radical solutions to these social problems and negative phenomena, because these problems and phenomena are often renewed due to the presence of the main reason for their renewal in societies, which is the deterioration of economic conditions. And as it is well known that the poor economic conditions in any country contribute directly to the creation of many social diseases and problems, and negative phenomena in the society of that state. Therefore, it will be economically and socially feasible to address the causes of these social diseases and problems, and negative phenomena rather than their symptoms. The right thing to do is to harness corporate donations to boost the national economy and achieve the economic well-being for those societies. That luxury " economic well-being" will contribute to reducing the level of social problems and diseases, and negative phenomena in those societies. Adopting this approach will help address the roots of the problem, not its symptoms. Corporate donations in developing and poor countries can be a stone for more than one bird " promoting the national economy and achieving the economic well-being for societies, in addition to contributing to solving many social problems and diseases, and negative phenomena resulting from the deterioration of economic conditions."; The developing and poor countries suffer from a scarcity of economic resources, which are one of the requirements for comprehensive development. Therefore, they resort to borrowing from external sources, such as the World Bank and friendly countries. Mostly, these loans made poor and developing countries live in a spiral of economic bottlenecks" instead of moving forward, they were moving backward ". Funding development plans by relying on external loans is usually accompanied by many risks. These risks (failure of projects and inability to pay obligations) have contributed to the deterioration of economic conditions and the delay in achieving comprehensive development in most developing and poor countries. For this reason, it is necessary to search for more secure funding sources, and corporate donations can be one of those sources. 


\section{Lights on the Problem}

The problem of financing "economic resources" is one of the main obstacles to development in developing and poor countries. In developing and poor countries, corporate donations - as a source of financing, have not been properly used thus far in promoting inclusive development. Corporate donations are often used to address the symptoms of problems, not the deep root causes. Corporate donations should be directed towards addressing the economic problems that are a source of production for most of the social problems in contemporary societies in developing and poor countries. In these countries, the regulatory laws and financial policies did not take into account the principle of priority (the most important) and the principle of addressing the causes of problems instead of their symptoms as much as possible in organizing and managing corporate donations and investing them in a correct manner "in a fruitful way." Corporate donations are mostly directed towards charity, humanitarian aid and temporary solutions. It is a blind imitation of what is applied in developed countries whose economic conditions differ from those in developing and poor countries. Corporate donations can be used to promote economic development and address many social problems and negative phenomena resulting from deteriorating economic conditions, at the same time. In other words, using the donations provided by the donor corporations during a certain period to achieve two goals, "economic reform and social reform. "Corporate donations should be used for economic reforms and boosting economic development. This will contribute to solving many social problems and addressing many negative phenomena resulting from the deterioration of economic conditions. Unfortunately, this perception has not been adopted correctly. In our modern era, even if there are some ideas regarding investing corporate donations, such as establishing some productive projects for poor families in some countries, they are no more than initiatives to help those poor families and groups by opening the doors of livelihood in front of them that do not have a significant impact on the national economy of those countries. Often these initiatives are not systematic, not continuous and do not stem from deliberate strategic plans. Where corporate donations can be used to boost the national economy of the state in more than one axis in a better way than those initiatives "Dwarf Small Enterprises."

\section{The Importance of Studying}

The content of the idea of this study is "to move from treating the symptoms of the problem to addressing the causes of the problem" by redirecting corporate donations in the right direction, which may contribute to strengthening the national economy in developing and poor countries and solving many problems and social issues in those countries. Following this concept in designing appropriate financial policies regarding corporate donations may be a helpful factor in achieving comprehensive development in these countries.

\section{Objective of the Study}

This study aims to draw the attention of the governments of developing and poor countries to the need to reconsider their financial policies, laws and legislations regarding how to manage and invest corporate donations - as one of the sources of funding, to achieve comprehensive development in those countries in an ideal way, by redirecting these financial flows to be on the right track and in economically productive fields, according to the concept of priority (the most important) and the concept of treating the causes of the problem, not its symptoms, as much as possible.

\section{Study Methodology}

This study is classified within the studies concerned with presenting problems and proposals to solve them "problem and solution study." This study is theoretical that depends largely on the 
personal diligence " personal judgment" and rational thinking of the researcher supported by logical justifications in describing the problem and how to treat it in an ideal manner. As described in this study, the problem is not to exploit one of the sources of financing in developing and poor countries- which is corporate donations, in a correct and fruitful manner, and to submit a proposal on how to address this problem by envisioning a strategic economic plan to invest and manage this source in a fruitful way " according to the concept of strategic planning." In this theoretical study, the methodology of the literature review and the conceptual framework will be presented.

\section{Results " Expectations and New Ideas" \\ Expectations about the Proposed Plan}

The proposed plan in this study to invest and manage corporate donations in an optimal manner can contribute to strengthening the national economy of developing and poor countries in more than one axis as follows: Doubling the number of operating companies during a specified period; Increased productivity and high rates of economic growth within the country; Contribution to solving the unemployment problem; Increase the state's tax revenue in the coming periods; The return of the tax savings acquired by donor corporations to the state treasury; Strengthening the infrastructure in the country; Activating the role of financial markets and encouraging investment in the country; Encouraging donor corporations to make more donations and persevering in that; And also to contribute to solving many social problems resulting from unemployment and deteriorating economic conditions; In addition to creating another source of funding for NPOs other than corporations" the development of contemporary societies is a collective responsibility."

\section{New Ideas and Developments in the Thought of CSR}

This study contributed to the emergence of some new ideas and concepts such as: Fruitful corporate philanthropy "multi-purpose"; New principles that can be added to the list of principles of CSR, "the principle of priority (the most important) and the principle of addressing the causes of the problem not its symptoms as much as possible; CER at the level of the country's economy as a whole; CPR "Corporate Philanthropy " can be a stone for more than one bird; The CPR is to support the national economy of the state and contribute to solving many social problems resulting from unemployment and deteriorating economic conditions; The idea of proliferous" reproductive/ multiplying" corporations; The logical interaction between CPR and CER "achieving goals regardless of the method of commitment used."

\section{LITERATURE REVIEW}

\section{CSR is a Tool for Development}

In recent years, many initiatives have been launched that encourage corporations to invest their capital and profits in a responsible manner and improve the social and economic life of the community to which they belong, which indicates the growing and increasing awareness of the importance of social responsibility entrusted to institutions and corporations. Civil society's evaluation of private sector corporations no longer depends on their annual profits. Rather, its evaluation depends on new concepts such as "CSR" and the extent to which they apply sustainable programs that help corporations create an effective work environment capable of dealing with changing and accelerating developments.

The growing interest in important issues such as poverty, improving the standard of living and creating new job opportunities were among the most important reasons for interest in CSR programs, which are important issues that for a long time remained the responsibility of governments alone. However, with the increasing interest in CSR concept and sustainable 
development issues, and the emphasis on the importance of having an active role for private corporations and civil society institutions to contribute to promoting comprehensive development in contemporary societies, the interest in these concepts "CSR and SD" has increased (Al-Mutairi, 2017).

Corporations contribute - through their commitment to their social responsibilities "economic, legal, ethical and charitable, to promoting development within the societies in which they operate. The desired goal of adopting the idea of CSR in contemporary societies is to make corporations as true partner in achieving comprehensive development in those societies. After the governments of the countries became unable to achieve prosperity and well-being for their societies" through public sector institutions" due to the limited economic resources, it became necessary for the participation of private sector institutions "corporations" and NPOs in managing the wheel of development in the societies of these countries. Societies have come to view corporations as the first leader in achieving well-being for them through the adoption of those corporations for their social responsibility. CSR carries with it all the noble values, lofty principles and wonderful ideas that contribute to pushing the wheel of comprehensive development forward. Through their commitment to their charitable responsibility, corporations are now contributing to strengthening the country's infrastructure (building bridges and paving roads), combating poverty (supporting the poor with money or establishing productive projects for them), and solving many social problems (by supporting NPOs), etc. Also, the corporations' commitment to their economic responsibilities means the optimum employment of economic resources and thus strengthening the indicators of economic growth in the country. As for the corporations 'commitment to their legal and ethical responsibilities, it contributes to achieving social justice and ensuring that all stakeholders obtain their rights. As well as, corporations' commitment to the requirements of sustainable development means ensuring a decent life for current and future generations. In fact, all the benefits that can be realized by the commitment of corporations to their social responsibility are for the purpose of promoting comprehensive development in contemporary societies.

\section{Corporate Philanthropy}

Corporate philanthropy is a general term that includes all activities, programs and initiatives that corporations implement to support and improve the quality of life for specific target communities or society in general. Corporate philanthropy can include: Donations of money, time, and work "effort"; Collecting donations for a cause; Making interest-free loans ; Waiver of economic gains to others ; A reduction in the selling prices of goods and services in recognition of specific circumstances, in solidarity with people ; Permission to use fixed assets for specific periods " free of charge" for the benefit of certain sects and groups or for the sake of improving, supporting and developing the performance of specific institutions in society, or for the benefit of society as a whole. The researcher defines corporate philanthropy as follows: It is a set of charitable initiatives (material and non-material donations) adopted by corporations, which contributes to improving the quality of life within the communities in which they operate, which is voluntarily provided by those corporations without any legal coercion, in response to the aspirations of contemporary societies and their urgent desires to develop the role of corporations to be the ideal partner who will bear part of their worries and problems due to the inability of governments - in most countries of the world, to meet all the needs of their contemporary societies and achieve all their aspirations" (Saleh,2020: 85). Also in this study the researcher defines corporate philanthropy as follows: Corporate philanthropy is the material and immaterial sacrifices that corporations make for the benefit of other entities outside the walls and buildings of those corporations, without waiting for any economic benefits other than enhancing the competitive advantage. Corporate philanthropy in its broadest sense means improving the quality of life for the community or one 
of its sects by providing a helping hand and material and non-material assistance to all parties outside the corporation's walls and buildings.

\section{The Importance of Corporate Philanthropy in Contemporary Societies}

In light of population explosions in most countries of the world and the inability of governments to meet all the aspirations of their societies, and achieve well-being and prosperity for them - due to their scarcity of economic resources, as well as the emergence of social problems and negative phenomena resulting from the deterioration of economic conditions, the idea of CSR has emerged in order to create a positive and effective role for corporations in the communities in which they operate, including contributing to bearing part of the burdens of those governments and participation in achieving the aspirations of those societies. The philanthropy that donor corporations give to the communities in which they operate has had a great role in improving the quality of life in those communities. Donations in cash and in kind that corporations make to non-profit organizations are a source of funding for those organizations. As it is no secret to anyone that non-profit organizations have a positive role in social reform programs, they contribute to solving many social and environmental problems, addressing many negative phenomena, and providing material and moral support to many sects in contemporary societies. Donations made by donor corporations contribute to reducing government spending. Corporate donations are mainly to bear part of the obligations of governments that those governments are unable to fulfill due to their limited economic resources. They contribute to achieving comprehensive development that governments cannot achieve without the participation of these corporations. Corporate philanthropy as a source of finance is one of the methods of social solidarity to improve the quality of life for contemporary societies.

\section{Classification of Corporate Philanthropy}

By reviewing the historical developments and changes that occurred in corporations 'policies regarding how to adhere to their philanthropic responsibilities, the researcher classifies corporate philanthropy into six types, including the Fruitful Philanthropy (multi-purpose) that was devised in this study:

\section{Classical /Traditional Philanthropy}

This type was continuous until the emergence of non-profit organizations and charitable societies in most societies of the countries of the world, and this does not mean that this type is permanently interrupted, as many corporations still practice their charitable activities without the mediation of NPOs. Classical philanthropy is represented in all types of material and nonmaterial aid that corporations provide to the societies in which they operate, such as alms given to the poor and the needy, contribution to strengthening the state's infrastructure, participation in solving many social issues in those societies, etc. Often the amounts of subsidies are specified in the corporations' discretionary budgets as "planned expenditures." In the modern era, in many countries of the world, traditional philanthropy is considered a problem for corporations. Traditional philanthropy has become a point of contention between corporations and tax administrations. Tax administrations often do not recognize traditional corporate philanthropy when determining corporate income tax and granting tax incentives, as it is an entrance to the practice of many unethical behaviors.

\section{Philanthropy Mediated by NPOs}

After the peoples and their governments realized the importance of the role of non-profit organizations in improving the quality of life in contemporary societies, a trend supported by legal legislations appeared in many countries of the world, which stipulates the necessity of 
supplying "submitting" donations of the donor corporations to these organizations so that those governments could recognize the legitimacy of these donations.

\section{Urgent "Sudden" Philanthropy}

Often this type is unplanned and not included in the corporations' discretionary budgets, which is imposed by certain circumstances beyond the control of those corporations. This type is represented in the non-financial and financial aid provided by companies to their communities in which they operate in cases of natural disasters "earthquakes, floods, etc., "and also in cases of wars and outbreaks of epidemics with humanitarian, religious, economic or political motives.

\section{Strategic Philanthropy}

Strategic philanthropy is an approach by which corporate or business giving and other philanthropic endeavors of a firm are designed in such a way that it best fits with the firm's overall mission, goals, and values. Strategic philanthropy is an approach to business giving that seeks to achieve goals for the community or recipient of the giving and for the business itself as well. Strategic philanthropy is more carefully focused. It does not just address any legitimate need in the community but rather concentrates on those needs or issues that are consistent with or aligned with the firm's overall mission, objectives, programs, or products/services (Carroll, 2018:7). Strategic philanthropy is an effective way to combine a corporation's marketing goals with its desire to improve the well-being of the community in which it operates. Through strategic philanthropy, a corporation selects a philanthropic activity to support, which also brings some benefits back. This philanthropic activity needs to support the business objectives of the corporation. Therefore, what this company does is support both its own interests and the interests of a charity organization. For example, assuming that, Black Tiger Company for the manufacture of televisions, one of its marketing policies, is to provide free maintenance to its customer whose monthly income is less than $\$ 1,000$. The charitable economic policy of the Black Tiger Company will contribute to supporting low-income people and enhance its revenues from selling televisions.

\section{Sustainable Philanthropy}

Sustainable philanthropy can be interpreted from two angles:1) The continuing commitment of corporations to provide their charity "donations" to the communities in which they operate depends on the extent to which these corporations are convinced that their donations are not a waste of shareholders' money but rather an investment that results in achieving direct or indirect economic benefits "mutual interests between the corporation and society resulting from those donations." If companies are just being good and donating a lot of money to social initiatives then they will be wasting shareholders' money. That is not sustainable in the long-run, and shareholders will quickly lose interest. Michael Porter (Hopkins, 2019). For example: Free games halls for children in the supermarkets will be desired and recommended by shareholders for two reasons: A) They contribute to maximizing profit as a result of increasing sales volume; B) They contribute to improving the quality of life for a group of society namely children.2) The continued flow of social benefits resulting from the donations made by companies, whether for current or even future generations, "such as building a seaport in a city that benefits current and future generations." The term sustainable corporate philanthropy refers to the optimal use of corporate donations and not wasting corporate money to finance social activities that do not result in mutual benefits, or result in temporary benefits that are not characterized by a constant flow of benefits.

\section{Fruitful Philanthropy (Multi-Purpose)}

In this study, the term "Fruitful Philanthropy" is introduced for the first time, which can be defined as follows: Fruitful corporate philanthropy means investing a specified value from 
donations of donor corporations to finance and establish certain new economic projects "corporations"-while ensuring the survival and continuity of newly established projects in their economic activity, and reinvesting that value or its economic return to finance other economic projects or to strengthen the state's infrastructure. Managing the donations of donor companies in this way means strengthening the national economy of the country in more than one axis. Logically, strengthening the national economy will have positive repercussions that contribute to bringing about social reforms within the society of that state" Fruitful corporate philanthropy, in addition to being a means to enhance the national economy of the state, is also a means that contributes to addressing many social problems and reducing the negative phenomena resulting from the deterioration of economic conditions." The Fruitful corporate philanthropy can be likened to planting a Super Fruit Tree that gives each period more than one type of fruit. As mentioned in the proposed plan in this study, with the same donation value during a specific period, the state "government" can achieve the following benefits: Doubling the number of operating companies and increasing the productivity rate; Strengthening the state's infrastructure; Doubling the state's tax revenues in the coming periods; Reducing the unemployment rate; Improving the incomes of individuals; Improving living standards; Reducing social problems and negative phenomena resulting from the deterioration of the economic conditions in the country.

\section{CER at the Level of the Corporation's Economy}

Economic Responsibilities: "be profitable, maximize revenues and minimize expenditures." Economic responsibilities relate to business's provision of merchandise and services in community. Earnings result from this activity and are necessary for any other responsibilities to be carried out. It is assumed that corporations will be as profitable as possible, maintain a powerful competitive position and maintain a high level of operating efficiency. It is well known that many developing countries suffer from a shortage of foreign direct investment, as well as from high unemployment level and widespread poverty. It is no surprise, therefore, that the economic contribution of companies in developing countries is highly prized, by governments and communities, alike (Carroll, 1991: 40; Al Am, 2020:331). Some economists see these as the only logical social responsibility of corporations. Living up to their economic responsibilities requires managers to maximize earnings wherever and whenever possible. The fundamental responsibility of business is assumed to be providing merchandise and services to people at a reasonable price. In discharging that economic responsibility, the corporation also emerges as socially responsible by providing productive works for its labor force, and income tax payments for its local governments.

\section{CER at the Level of the Country's Economy as a Whole}

This concept should be strengthened and adopted in developing and poor countries, which particularly states the following: "when seeking to maximize profits, corporations must not harm the national economy of the state, even if the laws do not criminalize this. "Corporations should contribute to strengthening the national economy of the state, "strengthening the state's national wealth." Corporations are one of the main components of any country's economy, and they can influence it, either positively or negatively. We may applaud the profitable corporation" the company that made the highest profit, " and at the same time we may regret the negative effects this corporation has left at the level of the country's economy as a whole. For example, hiring foreign workers and ignoring national workers. This behavior " action" contributes to increasing unemployment rates in society and also contributes to the exit of hard currency outside the borders of the state. Another example, reducing sales prices in order to sell a larger quantity of products may contribute to pushing another competitor out of the market. CER can be viewed from two angles: maximizing the company's profit and strengthening the national economy of the state. 


\section{The Interaction between CER and CPR}

In developed countries, and in a competitive market environment, the interaction of the CER with the CPR can be described as follows: 1) The commitment to economic responsibility contributes to strengthening the commitment to philanthropic responsibility ;2) The commitment to philanthropic responsibility contributes to enhancing the competitive advantage of companies;3) Competitive advantage contributes to reinforcing the commitment to economic responsibility, and so on. It should also be noted that commitment to philanthropic responsibility may contribute to achieving economic savings "resulting from tax incentives." These savings contribute to strengthening the donor corporations 'economies. As for developing and poor countries, and in the absence of competitive markets, it can be said that, there is no reciprocal interaction between economic responsibility and charitable responsibility. The companies' commitment to their economic responsibility contributes to strengthening the commitment to their charitable responsibility. Philanthropic responsibility does not contribute to enhancing commitment to economic responsibility due to the absence of an important and influential role for competitive advantage in that environment. Commitment to charitable responsibility may contribute to achieving tax savings "resulting from tax incentives", but these savings do not have any positive impact on the economics of donor companies, because the values of sacrifices "donations" are greater than the values of the benefits gained "tax savings resulting from tax incentives. "

\section{Financing Development in Developing and Poor Countries}

There is no doubt that finance plays a major role in supporting and running the development process and moving the determinants of economic growth and sustainable development. It is also considered one of the main pillars for achieving the goals of the countries 'strategic plans (Talha, 2020: 19). The scarcity of economic resources is one of the main obstacles that hinder the implementation of comprehensive development programs and plans in developing countries, especially the poor ones. The economic resources in many of these countries are not sufficient to effect positive change in the indicators of economic growth. This may be a justification for explaining the slowdown in economic growth in these countries. As a result, these countries are still ranked in the list of developing countries. Some developing countries have designed a package of strategic economic plans in an attempt to get out of that list.

In the modern era, with massive population explosions, economic conditions worsened in developing and poor countries, "where unemployment indicators have increased, individual income levels have decreased, the specter of famine has become painfully familiar in world news reports, epidemics have spread, and civil wars have spread to more than one country." The international support and aid were not sufficient to bring about a significant change in the area of comprehensive development in those countries. The economic resources of these countries are very weak and insufficient to build huge economic edifices. As a result, many developing and poor countries resort to external financing sources, which are represented in World Bank loans and loans from friendly countries, as well as opening the door to unfair foreign investment. As it is known, a large part of the economic returns resulting from development projects financed by external loans goes to lenders, "paying the annual installments of debts and their interest." This is in addition to the risks related to the failure of the implemented development projects, which may cause heavy losses to the borrowing country. As for foreign investment, it certainly has a positive effect on economic growth rates, but not to the satisfactory extent, because the largest share of economic returns goes to the foreign investor and not the host country as a result of the huge concessions that the host country grants to foreign investors. 


\section{Sources of financing for development in developing and poor countries}

The sources of financing development plans and programs in developing and poor countries can be classified into two categories, which are internal sources and external sources. The external sources include the following: 1) External loans "the World Bank / friendly countries"; 2) Foreign investments; 3) International assistance. The internal sources include the following: 1) Available domestic economic resources; 2) Donations from companies and wealthy people " according to what is suggested in this study. "This source will have a positive impact in the field of economic and social development in those countries if it is invested and managed according to the method suggested by the researcher in this study.

\section{An Innovative Strategic Economic Plan}

Poor and developing countries should strive to boost their national economy by investing the available economic resources in an optimal manner and adopting all distinguished economic plans to achieve this goal. The strengthening of the national economy will contribute to improving the welfare level of the societies of those countries. To this end, governments will need massive funds to finance their economic plans. One of the available sources of funding is corporate donations. Unfortunately, this source is not exploited in an ideal way to bring about real economic development in developing and poor countries. Most corporate donations are made to support NPOs. As it is known that these organizations are often interested in addressing specific social issues that have no relationship or direct impact on the country's economic growth indicators. This does not mean diminishing the importance of these organizations to contemporary societies in solving many social and environmental issues and problems. In developed and rich countries, this policy can be accepted. As for developing and poor countries, according to the researcher, these donations should be used to boost the national economy of these countries. This means that other sources of funding for NPOs should be sought, in line with the concept of importance and priority. The question that arises: How can corporate donations be used to boost the nation's national economy? And how can NPOs be funded? There may be more than one way to do this. In this context, the researcher proposes the following strategic economic plan "the idea of proliferating corporations" which will reflect the utmost degrees of idealism regarding the optimal utilization of corporate donations in creating real economic development and strengthening the national economy in those developing and poor countries .That plan, that will contribute to strengthening the national economy of the state in more than one axis.

According to strategic planning thought, any strategic plan must be derived from a clear vision for the future. "The strategic economic plan should be derived from and consistent with the government's vision." The strategic economic plan for any country depends primarily on the government's vision of the current unsatisfactory economic situation and the desired future aspirations. The strategic economic plan is the path that must be followed to achieve this vision "the desired goal" by relying on specific capabilities and preventive measures to avoid any threats that may prevent the achievement of the desired goal. Logically, the ideal vision that all governments of developing and poor countries should adopt is: "Strengthening the national economy and pushing forward the wheel of development in order to achieve prosperity for society." Based on this vision, the government's mission can be visualized as follows: The government as an executive authority concerned with managing state affairs will work to strengthen the national economy and create real economic development that will contribute to achieving the economic well-being of its citizens and improving the level of per capita income by adhering to the implementation of a set of strategic economic plans, that embody the country's vision and aspirations for the desired future. This vision and desired aspirations will be translated into a group of necessary economic policies, measures and reforms in all the institutions of the state's 
economic entity. Strengthening the national economy will be through adopting a prudent economic policy that takes into account the following requirements: Optimizing the use of available economic resources and managing them in a productive way; Developing economic policies, financial laws and strengthening the infrastructure to attract foreign investments; Opening the door to economic partnerships with friendly countries "strengthening integrated strategic economic partnerships with friendly countries"; Establishing new economic projects with the need to stay away from foreign loans as much as possible.

There may be more than one strategic plan to achieve the desired goal, and the next is one of those plans.

\section{The Content of the Innovative Strategic Economic Plan "Corporate Donations as a Stone for more than One Bird"}

The idea of this innovative plan is to direct corporate donations to boost the national economy of the state in more than one axis in a fruitful way that will contribute to sustainable development and economic growth, and furthermore push forward the eradication of poverty. According to the researcher's opinion, the best way to achieve these desired goals is to double the number of corporations operating in the country in the coming periods with funding provided by donor corporations "corporate donations" In other words, the use of voluntary contributions provided by donor corporations to establish new corporations. This is what can be called the idea of the Proliferating/ Reproducing Corporations. According to this innovative plan, corporate donations can contribute to achieving the following economic and social benefits: Doubling the number of companies operating in the country in the coming periods (establishing new service, commercial and industrial institutions with funding from companies operating at the present time) and then increasing productivity and improving economic growth rates in the country; Increasing tax revenues in the coming periods; Return the tax savings - earned by donor companies, to the state treasury; Strengthening and developing the country's infrastructure; Encouraging local investment and activating the role of financial markets in the country; Donor companies will continue to make donations to the communities in which they operate- especially in a competitive market environment, as a result of the tax incentives" according to the scenario proposed by the researcher in this plan "; Promoting and developing the idea of social solidarity within the community " achieving prosperity is a collective and shared responsibility" to ensure the continued funding of NPOs according to the scenario proposed by the researcher in this plan "; Actual contribution to solving the problem of unemployment and addressing many social problems and negative phenomena resulting from the deterioration of economic conditions. These benefits can be achieved during the coming periods by the same amount of donations made by the donor corporations. It should be noted that, the greater the amount of the donation, the greater the amount of benefits.

\section{How to Implement the Plan}

This plan can be implemented by following all of the prescribed steps:

Funding NPOs is the responsibility of all employees and workers in the private and public sectors. It is a compulsory financing "compulsory deduction from their monthly salaries." All employees and workers in the country are obligated to pay a small amount that is deducted from their monthly salaries - half a dollar or a dollar per month, "mandatory payments" that is paid to the state treasury. Every employee or worker will be obligated to pay a small amount of his $\backslash$ her monthly salary. The economic entities " employers" are obligated to send and transfer the monthly total sums to the state treasury. After receiving these compulsory monthly deductions, the government takes charge of distributing these amounts to all recognized NPOs within the country. This policy is to ensure that NPOs will continue to carry out their duties and social 
activities. As for corporate donations as a source of financing, they should be invested in financing strategic plans related to strengthening the national economy of the country according to the following steps:

Donor corporations must make their donations to the state treasury; After receiving donations from donors, these donations should be used by the government to finance the process of establishing and forming new industrial, commercial and service corporations, based on economic feasibility studies prepared for this purpose; The government should determine the cost of establishing "construction costs" each new corporation; The government should divide the new corporation's capital, "the cost of its establishment " into shares; Those shares must be sold on the stock market by the government; The total value of the shares sold must be higher than the cost of establishing the new corporation ; The government must recover the value of tax savings that donor corporations have made " earned" in exchange for those donations. Those tax savings that contributed to the decrease in the value of government revenues from taxes; The government should invest the remainder of the stock sales value to strengthen the country's infrastructure; In order to motivate corporations to make their annual donations, the government must grant a full tax exemption in exchange for those donations. More precisely, these donations should be deducted from the fully taxable income.

\section{Comprehensive Development in Contemporary Societies in Developing and Poor Countries is a Collective Responsibility}

In view of the limited economic resources in developing and poor countries, and the urgent desire to achieve comprehensive development - that needs concerted efforts in these countries, the fiscal obligations of corporations and citizens "employees in the public and private sectors" must exceed the payment of taxes and go further than that. In those countries, according to the plan proposed in this study, corporations should make donations to boost the national economy and economic development, and employees should support NPOs, this is what can be called the collective responsibility. As it is known, and for the most part, NPOs are concerned with addressing social problems and negative phenomena within society. As for strengthening the national economy through the support "donations" provided by donor companies, it will contribute to improving the level of per capita income and reducing the unemployment problem. This approach has positive repercussions that contribute to solving many social problems and reducing the negative phenomena resulting from unemployment and deteriorating economic conditions.

\section{Proliferating / Reproducing/ Multiplying Corporations}

The Proliferating corporations is a new innovative term, used by the researcher for the first time to refer to: doubling the number of corporations operating in the country by relying on donations from corporations as a source to finance the establishment, formation and building operations of new corporations that did not exist in the past. The idea of the proliferating corporations means increasing the number of corporations in society by relying on the donations of the operating corporations as a source for the construction and establishment of new corporations. It should be noted that the idea of the proliferating corporations contributed to the production of the term "fruitful philanthropy" - multi-purpose, referred to in this study.

The proliferating / reproducing/ multiplying corporations can be defined as follows: They are the corporations that contribute through their donations to the establishment of new corporations. They are the corporations whose donations are used to establish other new corporations. These are companies that donate a portion of their profits to establish other new independent companies. An example to illustrate the idea, assuming that: In 2018, the Libyan government had adopted the idea of the proliferating corporations as one of the economic policies to boost the national economy of the Libyan state, which contributed to doubling the number of operating 
corporations in just two years, as follows: In 2018 the number of corporations operating in the city of Benghazi was 75 corporations. During the year, these corporations made their donations to the state treasury in the city of Benghazi, which were used to establish 25 new corporations. At the end of 2019, the number of corporations operating in the city of Benghazi increased to 100 corporations. In 2020, these corporations (100 corporations) made their donations to the state treasury in the city of Benghazi, which were also exploited to establish another 40 new corporations in the city of Benghazi, by the end of 2020, there were 140 corporations operating in the city of Benghazi. It is noticeable from this hypothetical example that the number of companies in the city of Benghazi increased by 65 companies.

\section{Developing the Principles of CPR in Developing and Poor Countries}

In order to achieve comprehensive development in developing and poor countries, all available economic resources must be properly utilized in fruitful areas. Corporate donations -as one of the sources of financing in those countries, should be directed to serve economic development, which will have beneficial repercussions beyond the economic gains such as reducing the level of social problems and diseases, and negative phenomena resulting from unemployment and deteriorating economic conditions. To achieve this goal" by making optimal use of the funds allocated by the donor corporations" all developing and poor countries must adopt the following two principles: The principle of priority (most important). Resources are limited, and there is something important and there is something more important. CPR does not only mean charitable spending, but it also means choosing where the right donation is" the right area to donate." In developing and poor countries, this principle indicates the urgent need to harness the corporate donations to finance the most important areas and putting this resource in its rightful place. Failure to make full use of corporate donations means wasting economic resources in these countries. In developing and poor countries, there should be clear financial policies and legislation to direct corporate donations to fund more important causes. And economic development is one of the most important of those issues in those societies, which must be given priority because it contributes to achieving comprehensive development. The principle of treating the root causes of the problem, not its symptoms whenever possible. NPOs financed by donor companies are mostly concerned with addressing many social issues, problems, and diseases, and negative phenomena resulting from unemployment and deteriorating economic conditions (deteriorating living conditions), such as addiction, reluctance to marry, prostitution, divorce, crimes involving graft, elderly care, orphan care, etc. The continuation of these organizations in carrying out their charitable activities depends on the continued flow of aid from donor companies and philanthropists in the community. In fact, the activities carried out by these organizations - including the provision of aid to those beneficiaries and affected, often do not contribute to solving many social problems and issues radically. For example, treating drug addicts does not mean addressing the addiction problem in society. The fundamental solution to this problem lies in the strict prevention of the drug trade within society. Mostly the support that NPOs provide to their communities is to treat symptoms of social problems and diseases, and negative phenomena in society. That support is for the service of specific sects and not for the community as a whole. They are temporary solutions and not radical. The support of society as a whole lies in eliminating the causes of these problems. The correct procedure is to address the causes of these social problems and negative phenomena and uproot the deep roots from which these problems and phenomena arise. Addressing symptoms without addressing the causes means a waste of economic resources, which are limited in developing and poor countries. Symptomatic treatment should be replaced by treating the causes and uprooting the roots that produce these problems, social diseases, and negative phenomena as much as possible. In developing and poor countries, unemployment and deteriorating economic conditions (low 
income level) are the deep roots from which most social problems and diseases and negative phenomena emanate in the societies of these countries. According to this perception, all developing and poor countries should adopt this principle.

\section{The Logical Interaction between CER and CPR at the Level of the Country's Economy and the Level of the Company's Economy "Proposed Plan"}

Theoretically, the thought of CSR showed the logical interaction between CPR and "CER at the level of the corporation economy" as follows: Corporate donations given to NPOs contribute to enhancing the competitive advantage and the latter contributes to enhancing the economic performance of companies " CER. " Promoting the corporation's economy and its growth is strengthening the state's economy, considering corporations are one of the components of the state's economic entity. Corporations are one of the main components in the economies of contemporary countries, and they are part of their national wealth. The growth and prosperity of the corporations will contribute to the growth and prosperity of the country's economy. Accordingly, it can be said that enhancing the CER "at the level of the corporation economy," which means profit maximization, will positively affect the improvement of indicators of economic growth of the country, and this is what can be considered as one of the requirements of CER "at the level of the country's economy as a whole." As a result of the interaction and mutual influence between the economy of the corporation and the economy of the state as a whole, the CER can be viewed from the point of view of the company's economy, "maximizing profit for the corporation," and from the point of view of the state's economy as a whole. "enhancing the economic growth indicators for the state." According to the proposed scenario, the commitment to CPR "corporate donations for economic purposes " is to enhancing the CER at the level of the country's economy as a whole, " the economic benefits that the proposed plan will achieve at the level of the country's economy as a whole," and to contribute to solving many social problems and addressing many negative phenomena resulting from unemployment and deteriorating economic conditions. This means harnessing the CPR to enhance the CER at the level of the country's economy as a whole. This means harnessing the CPR to enhance the national economy and address social problems and negative phenomena resulting from unemployment and deteriorating economic conditions. The final result of this idea is to enhance the competitive advantage of corporations that will contribute to improving the economic performance of those corporations " boosting the CER at the level of the corporations' economy, under the effective influence of competitive advantage in the market." Also, the CER "at the level of the state's economy as a whole" will be affected by the CER "at the level of the company economy", and the logical result of this mutual interaction is to strengthen the national economy and improve the level of welfare that will contribute to solving many social problems and reducing the rate of negativity phenomena resulting from unemployment and deteriorating economic conditions in the developing and poor country. This can be called the optimal exploitation" investment" of corporate philanthropy (multipurpose).

The next steps are to explain the logical interaction between CPR and CER "Harnessing the CPR to enhance the CER at the level of the state economy as a whole":

1) Commitment to the CPR for economic purposes contributes to enhancing the CER at the level of the state's economy as a whole; 2) Enhancing the CER at the level of the country's economy as a whole contributes to enhancing the competitive advantage of corporations; 3 ) The competitive advantage of companies will contribute to strengthening the commitment to CER at the level of the company's economy, "maximizing profits."; 4) Strengthening the CER at the level of the company's economy will contribute to enhancing the CER at the level of the state's economy as a whole, as companies are part of the state's economy. In addition to enhancing CPR, whether for economic or social purposes. But if there is no effective role for competitive advantage "resulting from 
corporate commitment to their social responsibility," then there will be no significant interaction between $C P R$ and $C E R$.

\section{The New Addition of the Thought of CSR " Classification of CER and CPR"}

Depending on the content of the idea of this study, CER and CPR can be precisely classified in line with the conditions prevailing in developing and poor countries as follows: CER "at the level of the corporation economy". It means maximizing profit by improving the level of revenues, reducing expenditures to the lowest possible level, and optimizing the use of available economic resources. Corporations are part of the state's economic entity and one of the main components of its national wealth. Enhancing the economic performance of corporations and its growth has positive repercussions on the country's economy as a whole; CER "at the level of the country's economy as a whole "; It means strengthening the national economy of the state and its infrastructure, and contributing to the prosperity of the society that allowed these corporations to carry out their economic activities. This can be achieved through: Not to cause any economic crises within the state, even if the laws in force do not criminalize the economic decisions taken by corporations; Not to inflict economic damage on any other economic entity, even if it is legally permissible, in order to achieve economic gains in light of competition. As the loss of any economic entity is a loss to the national economy of the state. In order to maximize profits- which is a legitimate goal for all corporations, care must be taken not to inflict economic damage on other economic entities. The end result is the realization of gains for one entity and losses for another, and perhaps the loss of that affected entity forever, and this negatively affects the economy of the country as a whole; Investing and exploiting the available economic resources in an optimal way" economic rationality"; Providing support and assistance to local economic entities as much as possible to overcome their ordeal; Purchases of raw materials and supplies should be concluded with local economic entities as much as possible, to limit the flow of money out of the country; Employment of national labor to reduce the phenomenon of unemployment ; Seizing all opportunities and economic gains provided by the international environment as much as possible; In light of the difficult economic conditions, corporations must provide their donations and loans to economic entities to help them overcome their economic ordeal to avoid foreign loans that have exhausted the shoulders of developing and poor countries. The interaction between the CER "at the level of the company economy" and the CER "at the level of the state economy as a whole" lies in the fact that commitment to the first contributes to strengthening the economy of the country as a whole, which means strengthening the CER at the state level as a whole. Also, commitment to the first, without taking into account the conditions of other economic entities, or not adhering to this responsibility efficiently, may contribute to causing economic damage to the economic entity of country. CPR "donations for economic purposes." Exploitation of corporate donations to support the national economy of the state and strengthen its infrastructure can be considered as enhancing the CER "at the level of the state's economy as a whole." This approach contributes to achieving two goals: The first is to strengthen the national economy of the state; And the second is to contribute to solving many social problems and reducing the growth rate of negative phenomena resulting from unemployment and deteriorating economic conditions, "a decrease in the level of per capita income." CPR "donations for Economic Purposes" should be adopted in developing and poor countries due to the abundance of its benefits on the economic and social levels. Certainly, the donations of the donor corporations will contribute to enhancing the competitive advantage of these corporations, which will contribute to enhancing the economic performance of the corporations. CPR "donations for social purposes." Corporate donations devoted to supporting NPOs contribute to solving many social and environmental problems and issues, combating negative phenomena and developing contemporary societies. Also, these donations contribute to enhancing the competitive advantage 
of donor companies, which positively affects the economic performance of these corporations. In other words, the competitive advantage contributes to enabling the donor corporations to adhere to their economic responsibility "at the level of the corporation's economy."

\section{The Economic and Social Returns of the Innovative Plan}

The innovative strategic economic plan will contribute to strengthening the national economy of the developing and poor country in more than one axis in addition to contributing to solving many social problems and issues resulting from unemployment and deteriorating economic conditions "low income levels." The economic and social returns of this plan can be identified in the following points: Doubling the number of companies operating in the country- during the coming period, will contribute to increasing productivity, improving the income levels of individuals and indicators of economic growth; This plan will contribute to solving the unemployment problem in the country, "employing people in new companies" and also reducing the value of the social benefits" social assistance" that the government provides to the unemployed people; This plan will contribute to enhancing government revenue from taxes in the future, "increasing the value of government revenue from taxes due to the increase in the number of corporations within the state."; This plan will contribute to strengthening the country's infrastructure, "sales of shares of new corporations will be used by the government to strengthen the country's infrastructure."; This plan will increase the volume of investment in the country ( encouraging investment ) "investing instead of hoarding "increasing the volume of investment and activate the role of financial markets."; This plan will enable donor corporations to make tax savings. These economic benefits will serve as an incentive for corporations to continue making donations that are the source of funding for the proposed plan; This plan will allow the government to sell shares of new corporations "to collect the total value of donations made by donor companies," and thus the government can return the value of tax savings achieved by donor corporations. Under this plan, the state's tax revenues will not be affected; This plan will contribute to reducing unethical practices and behaviors that donor corporations can engage in through donation activities" all corporate donations will be under government control"; This plan will contribute to promoting the idea of true social solidarity within the community. NPOs will be funded by employees and workers in the public and private sector and not by corporations. "The welfare of society is a collective responsibility in which all entities within society must contribute" individuals, institutions, corporations, governments, etc." But each entity has a specific contribution in a specific area; This plan will contribute to solving many social problems and eliminating many negative phenomena resulting from unemployment and deteriorating economic conditions within society.

\section{A HYPOTHETICAL EXAMPLE}

Assuming that, in 2000, in one of the developing countries, the number of operating companies was 800 . The number of employees and workers in the public and private sectors was 10,000,000. The total value of corporate donations was $\$ 350,000,000$. The value of tax savings made by donor corporations during 2000 was $\$ 150,000,000$. In 2001, relying on corporate donations as a source of financing" according to the proposed plan in this study," the government has created 10 new corporations. The government sold shares of the new corporations at a value of $\$ 500,000,000$. The government recovered the value of tax savings " $\$ 150,000,000$ " that were achieved by donor corporations for 2000 " the decrease in the income tax of donor corporations in 2000." The government spent \$350,000,000 "remaining amount of stock sales" in the field of strengthening the country's infrastructure, "new roads and bridges." Employing more than 8,000 people in the new corporations. As a result of the increase in the number of corporations, the value of the state's tax revenues increased in 2001 by $20 \%$. As a result of employing employees and workers in new corporations, the value of social benefits" subsidies" provided by the government to the unemployed decreased in 2001 by $\$ 14,000,000$. In the event that this plan is implemented for more than a year, the 
number of companies operating in that country will double, the government's tax revenue will increase and the unemployment rate will decrease.

Adopting this strategic economic plan will contribute to achieving economic gains in more than one area. Those gains will contribute in a positive and effective way to strengthening the national economy of the country. Those gains are: contributing to solving the unemployment problem and to improving the economic status of people; To contribute to reducing government spending in the field of social benefits" subsidies" provided to the unemployed; Contributing to increasing productivity and competitiveness in the country; Encouraging investment (investing instead of hoarding)" increasing the volume of investment" and activating the role of financial markets; Contributing to increasing government revenue from taxes due to the increase in the number of corporations; contributing to strengthening the country's infrastructure, etc.

\section{Requirements for Implementing the Innovative Plan:}

To ensure the achievement of the intended purpose of adopting this idea, the authorities in developing and poor countries must observe the following requirements:

\section{Amending the Law on Funding NPOs}

Funding for NPOs should be through private and public sector employees and other donors, not through operating corporations. With regard to employees, small amounts are deducted from their monthly salaries and transferred to the state treasury through the institutions "organizations" in which they work. The government's role is to redistribute the total amount to the recognized NPOs according to their needs for funds and importance of their activities. All sums must be transferred to the state treasury as a first step, and then redistributed to NPOs. With this regulatory action, all unethical practices that could be passed by donor corporations when dealing directly with NPOs will disappear.

\section{Development of the Tax Treatment Law for Corporate Donations}

The tax treatment that fits with this plan and that will motivate the donor corporations to continue making their donations to the communities in which they operate is to deduct the donation value from the taxable income in order to allow these corporations to achieve tax savings "economic gains." Therefore, the corporate income tax law should include a reference to the necessity of granting full tax incentives to donor corporations. In other words, corporate donations should be treated as if they are operating expenses that are deducted from revenues or taxable income.

\section{Issuing a New Law Regarding Corporate Donations}

To implement the established plan with extreme accuracy, there must be legislation that compels all parties "the executive authority, corporations, etc." to adhere to the content of the plan and policies and procedures described to implement it. Legal legislation should include the following:1) Corporate donations must be transferred " submitted" to the state treasury;2) Using the donation funds to establish new corporations;3) Selling new corporations at a price higher than the cost of their establishment" building and construction";4) Return the tax savings -earned by donor corporations, to the public treasury" the difference between the cost of establishing and building new corporations and the selling value of these corporations should equal the value of the tax savings earned by the donor companies or more than it "; 5) The remaining amounts, which are the cost of establishing and building new corporations, must be invested in strengthening the country's infrastructure.

\section{Informing all Concerned Parties of the Content of the Plan}

All the stakeholders (all parties involved) who affect and are affected by this innovative strategic economic plan must be aware of the content of the plan, its objectives, and its economic and social benefits. The success of implementing this plan depends primarily on the conviction of all 
concerned parties of the importance of its role in promoting the national economy of the state, and the insistence of these parties to achieve the desired goal of the established plan. This knowledge may create new perceptions regarding improving and developing the process of implementing the plan in a more efficient and effective manner through what may be submitted of proposals about it. In order to inform all people of the established plan and receive responses about it, it would be better to publish this innovative plan in all available media in the country.

\section{CONCLUSION}

Managing and investing corporate donations as mentioned in this plan is considered an embodiment of the concept of fruitful corporate philanthropy "multi-purpose". This visualization "conception" represents one of the recent innovations in developing the concept of corporate philanthropy" strategic philanthropy - sustainable philanthropy - and last but not least, fruitful philanthropy "multi-purpose"." This is what can be called the optimal use of corporate donations, especially in developing and poor countries. Adopting this plan can contribute to strengthening the national economy, as well as contributing to solving many social problems and eliminating many negative phenomena resulting from unemployment and the deterioration of economic conditions in those countries. Also, this perception embodies the true meaning of the idea of CER "at the level of the country's economy as a whole." As the correct orientation and optimal investment for the CPR, "the optimal use of corporate donations" to enhance the national economy in developing and poor countries is nothing but a commitment that can be included within the requirements of CER in a broad sense" at the level of the country's economy as a whole." CPR will achieve its goals, but through CER. Improving people's living conditions and contributing to reducing unemployment rates will contribute to solving many social problems and treating many negative phenomena resulting from deteriorating economic conditions and high unemployment rates. The new idea in this study is that corporate donations can be used in the following two areas: 1) In the field of social reform, which is the usual field; 2) In the field of economic reform, "strengthening the national economy." This field can be included in the requirements of the CER at the level of the country's economy as a whole. 


\section{REFERENCES}

Al Am, AlAline (2020). The Lebanese Students' Awareness on the Concept of Corporate Social Responsibility. Athens Journal of Business \& Economics . 6(4) : 331-348

Al-Mutairi, Dalal Mohammed (2017). Corporate social responsibility. Albalagh. Retrieved from: https://www.balagh.com/article/.

Carroll, A. (1991). The pyramid of corporate social responsibility: Toward the moral management of organizational stakeholders. Business Horizons, 34(4), 39-48.

Carroll, Archie B. (2018). Strategic Philanthropy . The SAGE Encyclopedia of Business

Ethics and Society. Retrieved from: https:// www.researchgate .net/publication /327 100 647_Strategic_Philanthropy

Hopkins, Michael(2019). Sustainable Philanthropy. Retrieved from: https:// www. researchgate. net / publication /335082891

Porter, Michael E. and Kramer, Mark R. (2002). The Competitive Advantage of Corporate Philanthropy. Harvard Business Review. Retrieved from: https:// hbr.org / 2002/12/thecompetitive-advantage-of-corporate-philanthropy

Saleh,Younis A. Battal (2020).Advantages And Disadvantages Of The Four Methods Of Tax Treatment Of Corporate Monetary And In-Kind Donations: A Theoretical Study Of Intellectual Enrichment In The Fields Of Taxation And Corporate Philanthropic Responsibility .JOBMER ,4 (1), 74-139.

Talha, Alwaleed Ahmed (2020). Strategic economic planning and future visions in the Arab countries. Arab Monetary Fund. Retrieved from: https://www. amf.org.ae/ar / study/bookof-economic-strategic-planning-and-future-visions-in-the-arab-countries. 